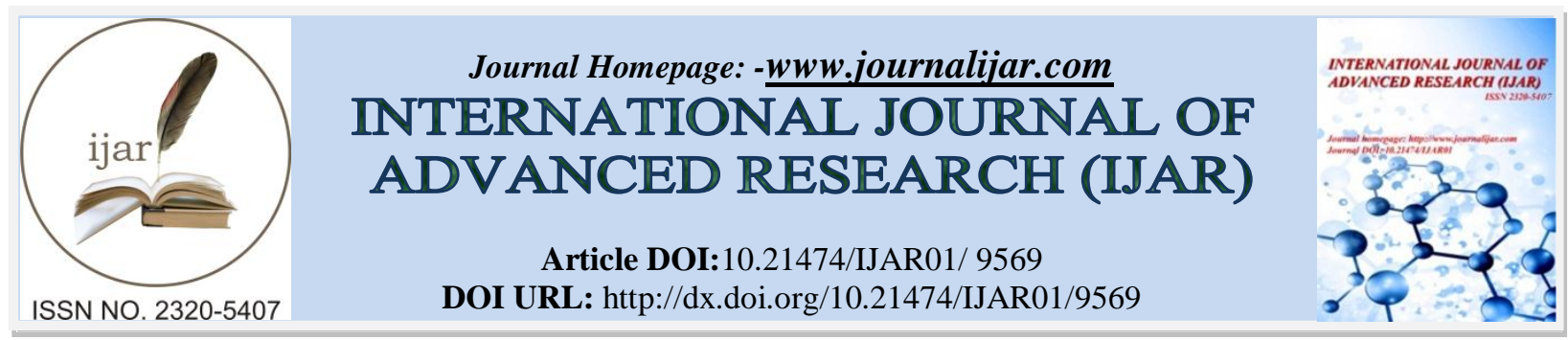

RESEARCH ARTICLE

\title{
EEFECT OF ORGANIC MATERIALS AND ZA (ZWAVELZURE AMMONIAK) FERTILIZER TO GROWTH AND YIELD OF SHALLOT IN ULTISOL SOIL IN WEST SUMATERA, INDONESIA.
}

\author{
Indra Dwipa ${ }^{1}$, Oki Putra ${ }^{2}$, Nasrez Akhir ${ }^{1}$ and Dedi Azwardi ${ }^{3}$.
}

1. Lecturer, Department of Agronomy, Faculty of Agriculture, Andalas University, Padang, West Sumatera, Indonesia.

2. Department of Agronomy, Faculty of Agriculture, Andalas University, Padang, West Sumatera, Indonesia.

3. Researcher, Balai Pengkajian Teknologi Pertanian Sumatera Barat. Sukarami, Solok, West Sumatera, Indonesia.

\section{Manuscript Info}

(.........................

Manuscript History

Received: 12 June 2019

Final Accepted: 14 July 2019

Published: August 2019

Key words:-

Organic material, shallot, ZA.

\section{Abstract}

The research aimed to study the interaction of several organic materials and ZA fertilizer. The research was conducted in August to November 2018 in experimentc al garden of Faculty of Agriculture, Andalas University. Factorial design in Completely Randomized Design was used in this research. The experiment consisted of 2 factors. The first factor was several types of organic material with 3 treatments, 25 ton/ha of chicken manure, 25 ton/ha of cattle manure and 25 ton/ha of husk charcoal. The second factor was dose of ZA fertilizer with 4 treatments, no ZA application, $300 \mathrm{~kg} / \mathrm{ha}, 400 \mathrm{~kg} / \mathrm{ha}$ dan $500 \mathrm{~kg} / \mathrm{ha}$. The data was analysed by $\mathrm{F}$ test in $5 \%$ and followed by Duncan's Multiple Range Test (DNMRT) in 5\%. The result showed that the best interaction occured in dose 25 ton/ha of husk charcoal and ZA 500 $\mathrm{kg} / \mathrm{ha}$. This interaction affected the diameter of tuber, fresh and dry weight of tuber per hectare. $500 \mathrm{~kg} / \mathrm{ha}$ of ZA affected the best number of tuber and 25 ton/ha of chicken manure affcted the plant high of shallot plant.

Copy Right, IJAR, 2019,. All rights reserved.

\section{Introduction:-}

Shallot (Allium ascolanicum) is main horticulture commodity that widely consumed by human in the world as spice for food after chilli [1]. Beside beeing as spice, shallot also is sold for vaious products such as shallot extract, shallot powder, essential oil, fried shallot even as medicine for cholesterol level, blood glucose, avoiding blood clotting, decreasing blood pressure and expedite blood flow [2]. As horticulture commodity, shallot is potencial to be developed not only for domestic but it can be also exported to other countries.

Shallot can be cultivated in low land ( $1 \mathrm{~m}$ above sea level (asl)) to highland (> 1000 asl). Shallot can grow well in humidity 80-90 \%, fertile and loose soil and contanis organic matter, porous soil structure and pH 5.5-6.5 [3]. The well growth and maximal yield can be obtained if the plants are cultivated in altitude up to 250 asl. The shallot grow well in dry climate and hot temperature and obtain sunlight more 12 hours for growth and formation of optimal tuber. The appropriate temperature for shallot growth is $25^{\circ} \mathrm{C}-30^{\circ} \mathrm{C}$ [4]. 
Production of Shallot in Indonesia in 2016 was 1,446,859 ton in width of land 149,635 ha with the productivity 9.67 ton/ha. In 2017, shalllot production was 1,470,155 ton in width of land 158,172 ha with productivity 9.29 ton/ha [5]. According the data, national production of shallot decreased. Since 2016, Indonesia goverment has stopped shallot import and started exporting shallot to overseas such as Singapore, Malaysia, Thailand and Vietnam.

Increasing of production quality of shallot yield can be done through 2 factors, intensification and extensification. Extebsification effort is done through new land clearing for agricultural. One of way is ultisol soil use. $25 \%$ of Indonesian land is ultisol soil. The widest land is in Borneo, followed by Sumatera particularly Riau Province and followed by North Sumatera [6].

Ultisol soil in Indonesia are still not used due to unfertile soil, low organic content, $\mathrm{N}$ and $\mathrm{P}$ availability is low and low $\mathrm{pH}$ (5.5) [7]. However this land is actually potential to develop as agricultural activities. For solving the ultisol problem, many efforts can be done such as increasing soil productivity through organic matter. Organic matter consists of organisme matter such as decomposition of plants, animals and human waste. One type of ogranic matter is manure. Manure is waste of animal that undergoes decomposition as organic material for plant. Types of manure that were reported to increasing soil fertile were chicken manure and catlle manure. From waste of plant, a type of organic matter is husk charcoal.

Chicken manure significantly affected plant growth. This fertilizer contained macro and micro elements such as $\mathrm{Cu}$, Mn, Co and B that played a role for plant gwroth [8]. Several reports reported that the manure always has positive response for plant due to it is easier to decompose in soil and contains many essentila elements that required by plant. Cattle manure also has positive response for plant and it is valuable manure. It contains $60-70 \%$ organic matter, $2 \% \mathrm{~N}, 1 \% \mathrm{P} 2 \mathrm{O} 5$ and $1 \% \mathrm{~K} 2 \mathrm{O}$ [9]. The advantage of this manure is the number of it is abundant and easy to obtain. The manure contains microorganisms that support decomposition process in soil [10]. The other organic matter is husk charcoal. Husk is part of rice grain, dry scaly, protecting inside part of grain. Main organic component in husk is $50 \%$ cellulose, $26 \%$ lignin, $4 \%$ organic component such as oil, protein and others [11]. Husk charcoal can be used for planting media and it contains high carbon and nutrient elements. Compounds in husk charcoal are $\mathrm{SiO} 2$ $52 \%, \mathrm{C} 31 \%$ and other compounds such as $\mathrm{Fe} 2 \mathrm{O} 3, \mathrm{~K} 2 \mathrm{O}, \mathrm{MgO}, \mathrm{CaO}, \mathrm{MnO}$ and $\mathrm{Cu}$ in low amount. Nutrient elements in husk charcoal are $0.32 \% \mathrm{~N}$, Phosporus $0.15 \%, 0.31 \% \mathrm{~K}, 0.96 \% \mathrm{Ca}, 180 \mathrm{ppm} \mathrm{Fe}, 80.4 \mathrm{ppm} \mathrm{Mn}, 14.10$ ppm Zn and ph 8.5-9.0 [12]. Husk charcoal application to soil increased soil fertile and plant production [13].

In tuber plants, ZA (Zwavelzure ammoniak) plays a role for improving tuber quality such as colour, flavour, taste and size of tuber. Bud and chlorophyll formation was significantly supported by ZA. ZA contains sulfur [14]. If sulfur content in plant is not enough, the leaves of plant undergo chlorosis. The reserach aimed to study the interaction of several organic materials and ZA fertilizer.

\section{Research Method:-}

The reserach was conducted in Experimental garden, Faculty of Agriculture, Andalas University, Padang, Indonesia from August to November 2018. The altitude of experimental place was \pm 250 above sea level (asl) and type of soil was ultisol. The variety of the shallot was Bima Brebes. Completely randomized design (CDR) with 2 factors was used in this research. The first factor was manure with 3 treatments :

1. A1 : Cattle manure (25 ton/ha)

2. A2 : Chicken manure (25 ton/ha)

3. A3 : Husk charcoal (25 ton/ha)

The second factor was ZA dose in 4 treatments used in this assay.

1. B1 : No ZA application

2. B2 : $300 \mathrm{~kg} / \mathrm{ha}$

3. B3 : $400 \mathrm{~kg} / \mathrm{ha}$

4. B4 : $500 \mathrm{~kg} / \mathrm{has}$

From these factors, 12 treatments were obtained and replied 3 times. 36 experimental units were obtained with population in a experimental unit was 50 plants. For each experimental unit, 12 plants as samplings. Size of experimental plot was $2 \mathrm{~m} \times 1 \mathrm{~m}$ and plant spacing was $20 \mathrm{~cm}$ x $20 \mathrm{~cm}$. The data was analysed by $\mathrm{F}$ test in $5 \%$ and followed by Duncan's New Multiple Range Test in 5\%. 
The field was prepared in first week and followed by tillage. Organic matter was applied in second week. The treatment was applied for each plot by applying various organic matter, $5 \mathrm{~kg} / \mathrm{plot}$ of cattle manure, $5 \mathrm{~kg} / \mathrm{plot}$ of chicken manure and $5 \mathrm{~kg} / \mathrm{kg}$ rice husk charcoal. They were sowed in plots surface.

The planting was conducted in third week. The seedling that used for this assay was Bima Brebes variety. Before planting, tip of tuber was cut $1 / 3$ and outer skin was removed for stimulating root growth and shoot. The seedling was entered in planting hole and each planting hole was filled by one bulb and covered by soil $2 / 3$ of bulb part. The planting space was $20 \mathrm{~cm} \times 20 \mathrm{~cm}$. The total of population in one plot was 50 plants and 12 plants as samplings.

The ZA application was conducted 2 times, half of dose in 10 days after planting and 28 days after planting. The doses of fertilization per plot were accorded to the treatments. The urea was applied 2 times and the second application was applied in 4 weeks after planting. First dose was $180 \mathrm{~kg} / \mathrm{ha}$, second application was $180 \mathrm{~kg} / \mathrm{ha}$. Urea was used as control to study the effect of sulphure in ZA fertilizer. Therefore, the fertilization was conducted with basic fertilizer, $150 \mathrm{~kg} / \mathrm{ha}$ of SP-36 and $90 \mathrm{~kg} / \mathrm{ha}$ of KCl.

The parameters that observed including height of plant, diameter of bulb per clump, number of tuber per clump, fresh weight per hectare and dry weight per hectare.

\section{Result and discussion:- \\ Height of plant}

The result showed that the interaction between organic matter and ZA did not affect the plant height of shallot. The effect only occured in single factor, manure (Table 1). For ZA single factor, it did not affect the plant height. This condition due to the application of ZA as sulphure source aimed to increase production and harvest quality of shallot. The manure affected the plant height due to each of manure contained different organic matter content. Chicken manure contained higher nitrogen and phosphate content than cattle manure and husk charcoal. It contained $2.33 \%$ of N, $0.61 \%$ P2O5 [9] . Cattle manure contained $2.33 \%$ N, $0.61 \mathrm{P} 2 \mathrm{O} 5$ and husk charcoal contained $0.32 \%$ of $\mathrm{N}$ and $0,15 \% \mathrm{P}[15]$.

Chicken manure could supply well nutrients due to one of its function was improving soil physic and structure, permeability and soil temperature so that the plant could absorb nutrients from soil. The plant growth of shallot was also influenced by soil $\mathrm{pH}$. Ultisol was heavy structure with low nutrients and $\mathrm{pH}$ content, the treatment of chicken manure could increase soil $\mathrm{pH}$ form 5.2 up to 6.5. If soil was too acid, the plant became stunt and if it was too alkali, the tuber became small and yield was low [16] .

The application of chicken manure could provide nutrients that required by plant in growth and development could be well absorbed by plant in ultisol by using $\mathrm{N}, \mathrm{P}$, and $\mathrm{K}$ to support plant height. $\mathrm{N}$ and $\mathrm{P}$ played a role in increasing vegetative growth particularly leaves, root and stimulated shoot and plant height [17][18]. The growth of plant would be inhibited if $\mathrm{N}$ was not enough absorbed by plant. The lackness of $\mathrm{N}$ in plant could be seen from the plant became stunt and the growth was inhibited. The other symptoms were the leaves were light green and yellowing. For N lackness symptom, the growth went slowly, weak and stunt [19].

Table 1:-Height of shallot plant with application of several organic matter and ZA $(\mathrm{cm})$

\begin{tabular}{|l|c|c|c|c|c|}
\hline \multirow{2}{*}{ Organic matters } & \multicolumn{3}{|c|}{ ZA fertilizer (kg/ha) } & \multirow{2}{*}{ Average } \\
\cline { 2 - 5 } & No ZA & 300 & 400 & 300 & \\
\hline Cattle manure & 37.69 & 33.30 & 34.49 & 36.54 & $35.54 \mathrm{~b}$ \\
\hline Chicken manure & 39.55 & 40.97 & 39.08 & 39.93 & $39.93 \mathrm{a}$ \\
\hline Husk charcoal & 32.66 & 39.08 & 35.58 & 33.80 & $33.80 \mathrm{~b}$ \\
\hline Average & 36.63 & 37.78 & 36.38 & 37.38 & \\
\hline CoD = 8.32\% & & & & & \\
\hline
\end{tabular}

The similar uppercase and lower case are different significantly according DNMRT in 5\%

\section{Diameter of bulb}

The interaction between organic matter and ZA fertilizer affected the diameter of shallot bulb (Table 2). This condition due to organic matter could improve soil condition and increased the soil $\mathrm{pH}$. ZA did not react in low $\mathrm{pH}$ due to application of ZA caused the soil became acid. The result showed that interaction between husk charcoal and dose of ZA $500 \mathrm{~kg} / \mathrm{ha}$ was the best treatment for diameter of shallot bulb $(28.76 \mathrm{~kg} / \mathrm{ha})$. The result due to in ZA 
application in $500 \mathrm{~kg} / \mathrm{ha}$ could serve plant nutrients requirement. Furthermore, husk charcoal could improve the soil physic so that supported plant in absorbing nutrients optimally. Husk charcoal was soil improver that could improve soil characteristics in land rehabilitation and repaired plant growth. Addtion of husk charcoal into planting medium inceptisol soil that had bad drainage, it could improve number of pore spaces and accelerated soil drainage [11].

The application of urea with other organic matter did not affect the bulb of shallot. But, for application of ZA and organic matter affected the bulb diameter. This condition due to sulphure content in ZA manure. ZA was a artifial fertilizer that contained ammonium sulfate that design to increase the nitrogen and sulfur for plant. Za contained 24 of sulfur and $21 \%$ of nitrogen. Sulfure was essential element that required by plant in large number. The plant took sulfure from soil in $\mathrm{SO}_{2}{ }^{2-}$ form and small portion from air in $\mathrm{SO}_{2}$ form. The formation of sulfure in soil was organic and anorganic [20]. Half of sulfur in soil was orgnaic form. The other report reported that the increasing of alliin in leaves and plant tuber through increasing of sulfur availability, while the effect of nitrogen was not significant. In early stage of plant growth, the highest alliin content occured in leaves, after that it was distributed to tuber. The trabslocation caused the alliin content in tuber increased in harvesting. This condition described that the alliin content increased two time if sulfur was applied. This result also showed that the plant resistance by sulfur application [21].

Table 2:-Diameter of bulb of shallot plant with application of several organic matter and ZA (mm)

\begin{tabular}{|l|c|c|c|c|}
\hline \multirow{2}{*}{ Organic matters } & \multicolumn{4}{|c|}{ ZA fertilizer (kg/ha) } \\
\cline { 2 - 5 } & No ZA & 300 & 400 & 500 \\
\hline Cattle manure & $23.89 \mathrm{~A}$ & $25.52 \mathrm{AB}$ & $24.62 \mathrm{~B}$ & $26.24 \mathrm{~B}$ \\
& $\mathrm{c}$ & $\mathrm{ab}$ & $26.52 \mathrm{~A}$ & $26.15 \mathrm{~B}$ \\
Chicken manure & $24.45 \mathrm{~A}$ & $26.58 \mathrm{~A}$ & $\mathrm{a}$ \\
& $\mathrm{b}$ & $\mathrm{a}$ & $26.19 \mathrm{~A}$ & $28.76 \mathrm{~A}$ \\
Husk charcoal & $23.63 \mathrm{~A}$ & $24.84 \mathrm{~B}$ & $\mathrm{~b}$ & $\mathrm{a}$ \\
& $\mathrm{c}$ & $\mathrm{bc}$ & & \\
\hline CoD $=3.19 \%$ & & & & \\
\hline
\end{tabular}

The similar uppercase and lower case are different significantly according DNMRT in 5\%

The application of husk charcoal could also increase the plant production. Husk charcoal played role as soil conditioner, increased the plant growth, maintained nutrients and improved soil biology. Husk charcoal played role as nutrients binder if the excess nutrients occures and lackness of nutrients absorption, the nutrients were slowly released or slow release [11].

\section{Number of tuber per clump}

The result showed that the interaction between organic matter and ZA did not affect the number of tuber per clump. But, the effect occured in single factor, the ZA application (Table 3). There was no effect of interaction between organic matter and ZA due to the application of organic matter could support tuber growth. The effect of single factor in ZA application due to the ZA function could increase the yield production, increased tha plant resistance to pests and diseases, drought and repaired the taste and color of shallot yield [22].

Table 3:-Number of bulb per clump of shallot plant with application of several organic matter and ZA

\begin{tabular}{|l|c|c|c|c|c|}
\hline \multirow{2}{*}{ Organic matters } & \multicolumn{3}{|c|}{ ZA fertilizer (kg/ha) } & \multirow{2}{*}{ Average } \\
\cline { 2 - 6 } & No ZA & 300 & 400 & 500 & \\
\hline Cattle manure & 6.11 & 5.69 & 5.94 & 6.94 & 6.17 \\
\hline Chicken manure & 5.69 & 6.52 & 6.44 & 6.33 & 6.24 \\
\hline Husk charcoal & 5.80 & 5.88 & 6.88 & 6.91 & 6.36 \\
\hline Average & $5.86 \mathrm{~B}$ & $6.03 \mathrm{~B}$ & $6.42 \mathrm{AB}$ & $6.72 \mathrm{~A}$ & \\
\hline CoD $=6.4 \%$ & & & & & \\
\hline
\end{tabular}

The similar uppercase and lower case are different significantly according DNMRT in 5\%

The result described that higher application of ZA, the number of bulb was more. The condition due to the nitrogen did not significantly affect the leaves number and bulb of shallot. ZA contained ammonium sulfur that played role as to increaase the quantity and size of bulb. The high absorption of sulfur in shallot affected the high requirement of 
sulfur. Appropriate dose or level of sulfur determined the growth and bulb quality. The availability of sulfur was required by plant to grow untill the shallot produced bulbs. The role of sulfur to plant growth was significant [23].

The plant required the sulfur as phosporus number. Sulfur was found in cystine, cysteine and methionine, amino acids that bulit protein of plant. Sulfur activated certain enzyme system and played role as component in several vitamins. Eventhough the sulfur was described as secondary nutrient, most of plant did not undergo sulfur deficiency as nitrogen, phosporus and potassium [18][19]. Obviously, many cultivated plants contained large number of sulfur and phosphate. If plant underwent sulfur deficiency, the protein production decreased and the plant cell growth was in active and the leaves underwent chlorosis [24].

\section{Fresh weight and dry weight of bulb per hectare}

Bulb of shallot is valuable part of plant. The bulb is the main purpose in cultivating of shallot. According to result, interaction of organic matter and ZA affected the fresh weight of bulb. It described that application of organic mater and ZA in same time could increase the shallot bulb (Table 4).

Table 4:-Fresh weight of bulb per hectare of shallot plant with application of several organic matter and ZA (ton)

\begin{tabular}{|l|c|c|c|c|}
\hline \multirow{2}{*}{ Organic matters } & \multicolumn{4}{|c|}{ ZA fertilizer (kg/ha) } \\
\cline { 2 - 5 } & No ZA & 300 & 400 & 500 \\
\hline Cattle manure & $6.17 \mathrm{~A}$ & $7.40 \mathrm{~A}$ & $6.57 \mathrm{~B}$ & $8.37 \mathrm{AB}$ \\
& $\mathrm{b}$ & $\mathrm{ab}$ & $\mathrm{b}$ & $\mathrm{a}$ \\
\hline Chicken manure & $7.13 \mathrm{~A}$ & $8.28 \mathrm{~A}$ & $8.40 \mathrm{~A}$ & $6.93 \mathrm{~B}$ \\
& $\mathrm{a}$ & $\mathrm{a}$ & $\mathrm{a}$ & $\mathrm{a}$ \\
\hline Husk charcoal & $6.40 \mathrm{~A}$ & $6.90 \mathrm{~A}$ & $7.70 \mathrm{AB}$ & $9.28 \mathrm{~A}$ \\
& $\mathrm{~b}$ & $\mathrm{~b}$ & $\mathrm{~b}$ & $\mathrm{~A}$ \\
\hline CoD $=11.76 \%$ & & & & \\
\hline
\end{tabular}

The similar uppercase and lower case are different significantly according DNMRT in 5\%

Interaction between cattle manure and ZA, highest fresh weight yield of bulb per hectare occured in $500 \mathrm{~kg} / \mathrm{ha}$ application (8.37 ton). It due to the cattle manure contained macro elements suc as $\mathrm{N}, \mathrm{P}$ and $\mathrm{K}$ that required by plant. These elements also improved soil physic suc as aggregate, pores space number and water binding. Furhermore, in chicken manure and ZA application, the increasing offresh weight did not occur, but in $500 \mathrm{~kg} / \mathrm{ha}$ dose, the increasing occured. This condition due to the $\mathrm{N}$ excess in ZA and chicken manure so that it affected the fresh weight of bulb [15].

Interaction between ZA and husk charcoal was the best treatment for fresh weight of bulb in the assay (9.28 ton/hectare). It was due to husk charcoal was type of organic matter that could increase the soil $\mathrm{pH}$ and repaired the physic and chemical of soil so that ZA application could increase quality and yield of shallot. ZA could also bulb quality such as repaired the color, flavor, taste and bulb size so that the good bulb quality affected the fresh weight of shallot bulb [11][14].

Organic matter also supported the plant growth. The role of organic matter could be measured by 2 aspects, soil and plant. From soil, the weathering of organic matter could serve N, P and $\mathrm{K}$ in soil that required by plant, repaired the soil structure, soil aeration and soil physic [25][26]. From plant aspect, the result of organic matter could increase the availability of nutreints for plant and also could be directly arbsorbed by plant. Husk charcoal was a type of organic matter if it was applied into the soil, it could increase the soil fertility and plant production. It also played a role as nutrient binder when nutrient excess occured and absorbed the nutreints when they were lack so that the ZA application did not cause acidity of ultisol soil [6].

The fresh weight was also affected by water content of bulb. Organic matter that was applied, it had capacity to bind water, particularly organic matter that contained $\mathrm{K}$. If $\mathrm{K}$ content was high, the capacity to bind the water was high so that it influenced the photosynthesis and nutrient distribution in plant [27]. If plant underwent $\mathrm{K}$ lackness, the translocation of carbohydrate form levaes to other organs was inhibited so that the photosynthesis result was accumulated in leaves and the rate of photosynthesis decreased. Low yield of bulb was obtained in soil that contained low K content. Potassium played role as in translocation and assimilate, increasing the bulb size, number and yield of bulb [26]. The fresh weight was also affected by harvesting time. Best time for harvesting was in 
morning due to the respiration of plant was still minimum so that the water content was higher. Shallot bulb contained $80 \%$ of water [28].

Fresh weight was highly related to dry weight. The interaction between organic matter and ZA affected the dry weight of bulb. The result showed that Husk charcoal and $500 \mathrm{~kg} / \mathrm{ha}$ of ZA was the best treatment for dry weight of bulb (8.17 ton/hectare) (Table 5). The result was no different from fresh wieght.

Table 5:-Dry weight of bulb per hectare of shallot plant with application of several organic matter and ZA (ton)

\begin{tabular}{|l|c|c|c|c|}
\hline \multirow{2}{*}{ Organic matters } & \multicolumn{4}{|c|}{ ZA fertilizer (kg/ha) } \\
\cline { 2 - 5 } & No ZA & 300 & 400 & 500 \\
\hline Cattle manure & $4.97 \mathrm{~A}$ & $6.17 \mathrm{~A}$ & $\mathrm{ab}$ & $7.03 \mathrm{AB}$ \\
& $\mathrm{b}$ & $7.18 \mathrm{~A}$ & $\mathrm{~b}$ & $5.98 \mathrm{~B}$ \\
& $6.08 \mathrm{~A}$ & $\mathrm{a}$ & $7.27 \mathrm{~A}$ & $\mathrm{a}$ \\
\hline Chicken manure & $\mathrm{a}$ & $5.92 \mathrm{~A}$ & $6.42 \mathrm{AB}$ & $8.17 \mathrm{~A}$ \\
& $5.42 \mathrm{~A}$ & $\mathrm{~b}$ & $\mathrm{~b}$ & $\mathrm{a}$ \\
\hline Husk charcoal & $\mathrm{b}$ & & & \\
\hline CoD $=11.76 \%$ & & & & \\
\hline
\end{tabular}

The similar uppercase and lower case are different significantly according DNMRT in 5\%

The dry weight of the assay was still lower that description of the variety of the shallot (9.9 ton/hectare). Low of yield in the assay due to the adaptation of the plant. The variety (Bima Brebes) was obtained from Brebes, Central Java, Indonesia. Eventhough the variety actually was planted in lowland, it enabled to plant in highland. The adaptation was affected by environmental factor such as rain, temperature and duration of sunlight. Sunlight played important role in shallot life particularly in photosynthesis [29].

Dry matter was the balance between photosynthesis and respiration. Photosynthesis caused the dry weight of plant increased due to the $\mathrm{CO} 2$ taking and respiration caused tha dry weight decreased due to $\mathrm{CO} 2$ release. The production of plant was more accurate if measured by dry weight than fresh weight due to fresh weight was affected by humidity [27].

Time and criteria for harvesting significantly affected the decreasing of bulb. The harvesting could be conducted if $90 \%$ of leaves were yellowing and bulb neck was limp. At the time, the photosynthesis started to decrease and assimilate tended to play role as in filling of bulb. The drying of bulb caused the weight of bulb decreased and according the description of variety, the shringking of fresh weight of bulb was $21.5 \%$. The other report reported that the shrinking of bulb was generally $9.02-11.62 \%$ due to the drying was only conducted 3 hours/day for 3 days under sunlight [30]. The low of production was also affected by other enviromental factor such as type of soil. The soil that in the assay was ultisol. Ultisol soil contained low organic matter and low pH (4.5-5.0) [7]. In cultivating plant in this soil, organic matter was required to improve the soil characteristic [15][16][22].

\section{Conclusion:-}

Dose $500 \mathrm{~kg} / \mathrm{ha}$ of ZA fertilizer and husk charcoal affected the diameter of bulb and fresh and dry weight of bulb. $500 \mathrm{~kg} / \mathrm{ha}$ of ZA application was the best application for most number of bulb.

\section{References:-}

1. Fattorusso E, Lorizzi M, Lanzotti V, Scafati OT. 2002. Chemical composition of shallot (Allium ascalonicum Hort.). Journal of Agricultural and Food Chemistry. 50(20): 5686-5690

2. Motlagh HRM, Mostafaie A, Mansouri K. 2011. Anticancer and anti-infalamtory activities of shallot (Allium ascalonicum) extract. Archives of Medical Science. 7(1): 38-44

3. Tesfa T, Woldetsadik K, Bayu W. 2015. Shallot yield, quality and shelf-life as affected by nitrogen fertilizer. International Journal of Vegetable Science. 21(5): 454-466

4. Rahayu, Mujiyo, Arini RU. 2018. Land suitability evaluation of shallot (Allium ascalonicum L.) at production centres in Losari District, Brebes. Journal of Degraded and Mining Land Management. 6(1): 1505-1511

5. Statistics Indonesia. 2017. Indonesia in numbers and figures 2016. Statistics Indonesia. 
6. Prasetyo BH, Suharta N, Subagyo H, Hikmatullah. 2001. Chemical and mineralogical properties of ultisol of Sasamba area, East Kalimantan. Indonesian Journal of Agricultural Science. 2(2): 37-47

7. Kadir S, Ishizuka S, Sakurai K, Tanaka S, Kubota S, Hirota M, Priatna SJ, Juariah. 2001. Characteristics of ultisol under different wildfire history in South Sumatera, Indonesia: I. Physo-chemical properties. Tropics. 10(4): $565-580$

8. Biratu GK, Elias E, Ntawuruhunga P, Nhamo N. 2018. Effect of chicken manure application on cassava biomass and root yields in two agro-ecologies of Zambia. Agriculture. 8(4): 1-15

9. Abdelrazzag A. 2002. Effect of chicken manure, sheep manure and inorganic fertilizer on yield and nutrients uptake by onion. Pakistan Journal of Biological Sciences. 5: 266-268

10. Djaenuddin N, Faesal, Soenartiningsih. 2014. Isolation and effectivity examination of several local decomposer in decomposing corn plant waste. Biosfera. 31(2) : 49-55

11. Onggo TM, Kusumiyati A, Nurfitriana. 2017. The effect of the addition of husk charcoal and polybag size on growth and yield of grafted tomato plant Valouro cultivar. Jurnal Kultivasi. 16(1): 298-304

12. Theeba M, Bachmann RT, Illani ZI, Zulkefli M, Husni MHA, Samsuri AW. 2012. Characterization of Local Mill Rice Husk Charcoal and Its Effect on Compost Properties.Malaysian Journal of Soil Science. 16: 89-102

13. Nurhidayati, Mariati. 2014. Utilization of maize cob biochar and rice husk charcoal as soil amendments for improving acid soil fertility and productivity. Journal of Degraded and Mining Lands Management. 2(1): 223230

14. Bagdadi A, Halim RA, Ghasemdadeh A, Ramlan MF, Sakimin SZ. 2018. Impact of organic and inorganic fertilizers on the yield and quality of silage corn intercropped with soybean. PeerJ. 6: 1-26

15. Pujisiswanto H, Darwin P. 2008. Effect of cattle manure compost to growth and tomato yield. Prosiding Seminar Nasional Sains dan teknologi-II. Lampung University. 1-10

16. Prasetyo R. 2014. The use of various manure sources as N source in red chilli cultivation (Capsicum annum L.) in sandy soil. Planta Tropica JOurnal of Agro Science. 2(2) : 125-132

17. Hartatik W, Widowati LR. 2010. Manure. Balai Besar Litbang Sumber Daya Lahan Pertanian. Badan Penelitian dan Pengambangan pertanian. $92 \mathrm{p}$.

18. Fitriatin BN, Yuniarti A, Turmuktini T, Ruswandi FK. 2014. The effect of phosphate solubilizing microbe producing growth regulators on soil phosphate, growth and yield of maize and fertilizer efficiency on ultisol. Eurasian Journal od Soil Science. 3: 101-107

19. Leghari SJ, Awocho NA, Laghari GM, Laghari AH, Bhabhan GM, Talpur KH, Bhutto TA, Wahocho SA, Lashari AA. 2016. Role of nitrogen for review. Advances in Environmental Biology. 10 (9) : 209-218

20. Winda, P.H. 2017. The growth and yield of shallot (Allium ascalonicum L.) in several dose of ZA and straw application. (Thesis). Faculty of Agriculture, Andalas University. Padang, Indonesia

21. Qinzhu Z, Aihui V, Linghui K, Shan H. 2017. Characterization and immobilization of purified alliinase produced from shallot. Bioprocess Biotech. 7(5): 308

22. Ibeawuchi II, Obiefuna JC, Alagba RA, Okoli NA, Ofor MO, Emma-Okafor LC, Iwanyanwu UP, Nze EO, Peter-Onoh CA. 2015. Organic matter management for sustainable tropical crop production. Journal of Natural Sciences Research. 5(1): 153-63

23. Chandra N, Pandey N. 2016. Role of sulfur nutrition in plant and seed metabolism of Glycine max L. Journal of Plant Nutrition. 39(8): 1103-1111

24. Tesseraud S, Coustard MS, Collin A, Seiliez I. 2009. Role of sulfur amino acids in controlling nutrient metabolism and cell functions : implications for nutrition. British Journal of Nutrition. 101(8): 1132-1139

25. Olivar VT, Torres OGF, Patino MLD, Nava HS, Martinez AR, Aleman RMM, Aguilar LAV, Tejacal IA. 2014. Role of nitrogen and nutrients in crops nutrition. Journal of Agricultural Science and Technology

26. Prajapati K, Modi HA. 2012. The importance of potassium in plant growth. Indian Journal of Plant Sciences. 1: $177-186$

27. Weiwei H, Ratkowsky DA, Hui C, Wang P, Su J, Shi P. 2019. Leaf Fresh Weight Versus Dry Weight: Which is Better for Describing the Scaling Relationship between Leaf Biomass and Leaf Area for Broad-Leaved Plants?. Forests. 10 (256): 1-19

28. Major N, Ban SG, Urlic B, Ban D, Dumicic G, Perkovic J. 2018. Morphological and biochemical diversity of shallot preserved along the Croatian coast. Front. Plant Science. 9(1749): 1-14

29. Young DR, Smith WK. 1980. Influence of sunlight on photosynthesis, water relation and leaf structure in understory species Arnica cordifolia. Ecology. 61(6): 1380-1390

30. Ansar M, Wahyudi I, Baharudin. 2016. Growth and yield of shallot Lembah Palu variety on different direction and form of seedbeds growing on dry land. Agroland. 3(1): 14-21 